\title{
EMT Framework Propagating Beyond Its Borders: The Congruence with Non-European Professional Translators' Needs
}

\author{
El marco de referencia de EMT se expande más allá de sus fronteras: congruencia con \\ las necesidades de los traductores profesionales no europeos \\ Difusão do quadro do MET além de suas fronteiras: A conciliação com as necessidades \\ de tradutores profissionais não europeus
}

Mohammad Reza Esfandiari (http://orcid.org/0000-0003-1321-3382)

Department of Foreign Languages, College of Humanities, Shiraz Branch, Islamic Azad University, Shiraz, Iran

Helia Vaezian (http://orcid.org/0000-0002-0302-9373)

English Language Department, Khatam University, Tehran, Iran

Forough Rahimi* (http://orcid.org/0000-0002-4735-7176)

English Language Department, School of Allied Medical Sciences, Shahid Behehsti

University of Medical Sciences, Tehran, Iran
Recibido: $08-08-17$

Revisado: $25-09-17$

Aceptado: $30-11-17$

Publicado: $18-12-17$
ABSTRACT. Intercultural communication has escalated social demand for translator training programs which has led to attempts to provide a proper educational basis for translator training. There is also a general agreement among scholars that there should be reconciliation between training and the actual translation world and the market. The EMT (European Master's in Translation) Competences Framework is the most comprehensive framework and is an improvement to previous models focusing on practice-oriented dimensions. However, this framework has been developed based primarily on the requirements of European professional translators. This study was conducted to look into the compatibility of the EMT framework with the needs of non-European professional translators. To this end, a total number of 177 participants from 34 nationalities and 21 languages participated in a questionnaire survey that explored the compatibility of the EMT framework competences with the needs of non-European professional translators. The results indicated that the most compatible components with non-European professional
Keywords: Professional translators, translators' needs, translation competence,

translator training, EMT

Citar como: Esfandiari, M. R., Vaezian, H. \& Rahimi, F. (2017). EMT Framework Propagating Beyond Its Borders: The Congruence with Non-European Professional Translators' Needs. Revista Digital de Investigación en Docencia Universitaria, 11(2), 7-24. doi: http://dx.doi.org/10.19083/ridu.11.554

* E-mail: frahimidsbmu.ac.ir 
translators are the language, thematic, intercultural, translation service provision, information mining, and technological competences. The results obtained can provide insight for translator training program planners.

RESUMEN. La comunicación intercultural ha incrementado la demanda social por programas de formación de traductores y esto, a su vez, ha derivado en una serie de intentos para establecer una base formativa adecuada para la capacitación de los traductores. Existe, además, un consenso general entre los académicos en el sentido de que debe haber un acercamiento entre la capacitación y el mundo y el mercado reales de la traducción. El marco de referencia de competencias del EMT (Másteres europeos en traducción) es el marco más amplio existente y constituye una mejora con respeto a modelos anteriores que se centran en las dimensiones orientadas a la práctica. Sin embargo, este marco ha sido desarrollado sobre la base de los requisitos de los traductores profesionales europeos. Este estudio se llevó a cabo con el objeto de indagar sobre la compatibilidad del marco de referencia de EMT con las necesidades de los traductores profesionales no europeos. Con este fin, 177 participantes de 34 nacionalidades y 21 idiomas participaron en una encuesta que exploró la compatibilidad de las competencias del marco de referencia EMT con las necesidades de los traductores profesionales no europeos. Los resultados indicaron que los componentes más compatibles con los traductores profesionales no europeos son las competencias lingüística, temática, intercultural, de provisión de servicios de traducción, de búsqueda de información y tecnológica.

RESUMO. A comunicação intercultural gerou uma demanda crescente por programas de formação de tradutores que decorreram em tentativas para provir uma base educativa apropriada para esse tipo de formação. Existe também o consenso geral entre os acadêmicos sobre a necessidade de conciliar a formação, a realidade atual do mundo da tradução e o mercado. O Quadro de Competências do Mestrado Europeu em Tradução é o mais abrangente e um avanço com relação a modelos anteriores focados nas dimensões orientadas à prática. Contudo, este quadro baseia-se nas necessidades dos tradutores profissionais europeus. Este estudo pretende investigar a compatibilidade do quadro do MET com as necessidades de tradutores profissionais não europeus. Para isso, um total de 177 participantes de 34 nacionalidades e de 21 línguas responderam um questionário para perceber a compatibilidade das competências do quadro do MET com as necessidades de tradutores profissionais não europeus. Os resultados apontam que os componentes mais compatíveis com os dos tradutores profissionais não europeus são a competência linguística, a competência temática, a competência intercultural, a competência para oferecer serviços de tradução, a competência sobre informação sobre mineração, e a competência tecnológica, respetivamente. Os resultados obtidos podem oferecer uma perspectiva para a elaboração de cursos de formação de tradutores.

Palavraschaves:

Tradutores profissionais, necessidades

tradutores, competência tradutora, formação de tradutores, MET 
Social and economic needs for intercultural communication have underscored the significance of education-based Translator Training as a major debate in Translation Studies. A generally accepted and widely believed viewpoint is that translator training programs should conform to the needs of society and market. The objectives of translation training programs are closely linked to the notion of translation competence (Schmitt, 2012). Moreover, a need for more comprehensive, distinct education is required because different factors such as new information and communication technologies, geopolitical and societal changes, along with globalization are at play, which directly or indirectly influence the translation market, volume of translation, and text-types that translators should translate, and even the way translating is carried out. Therefore, it is now essential for translators to learn an extended range of activities, such as terminology management, translation software tool development, software localization, language project management, bilingual technical writing, and creation and management of multilingual web sites if they intend to be active in the translation profession (Kelly, 2005; Kiraly, 2003, 2004; Olvera-Lobo et al., 2005). As a result, training multi-professional translators is necessary to promote a high level of qualification (Mayoral, 2003).

In view of this, the Directorate-General for Translation of the European Commission decided to congregate and improve translation programs and translator training in Europe after the Bologna process and enlargement of the European Union. The European Master's in Translation (EMT) expert group made an attempt to provide the framework, which is coherent, highly standard, and compatible with the demands of the international environment. They proposed the framework of the competences, which could be utilized for an extended professional range. The working group prioritized the learning objectives expressed in terms of acquirable competences. The proposed competences cover six areas (EMT expert group, 2009). The competences of the framework are interwoven and interdependent and fall within both general and subject specific categories.

The EMT framework is an improvement of previous models presented earlier and incorporates the concepts existing in other models, classifies them, and operationalizes them through the inclusion of practice-oriented dimensions. This framework is primarily designed to promote quality standards in translator training within Europe and to boost the status of the translation profession in the European Union (EMT Expert Group, 2009). However, it is worthy of further investigation whether it is to be used to train non-European translators. In the same vein, Pym (2008) also states that contact with the labor market and input from the professionals can assist program designers in planning an efficient curriculum. Therefore, this study was conducted to investigate the compatibility of the EMT framework with non-European professional translators' needs.

\section{THE EMT FRAMEWORK}

The EMT framework is prepared by a group of experts from the European Master's in Translation for the translation professionals, by focusing on learning objectives in terms of competences. The competences that were proposed covered six interdependent areas (EMT expert group, 2009), both general and specific. Figure 1 presents the proposed competences of EMT. 


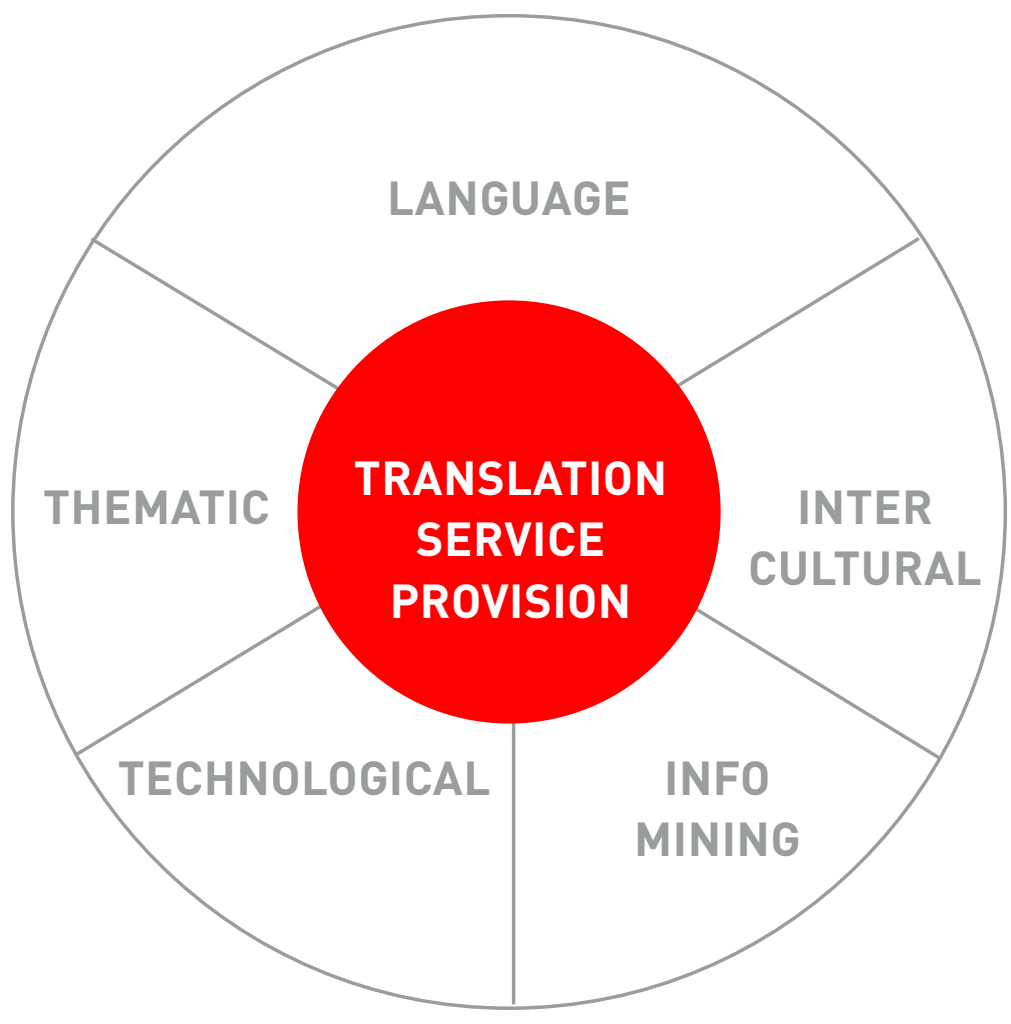

Figura 1. EMT competences

These components are both market-driven and practical and include the following.

\section{Translation service provision competence}

This competence combined some competences used in previous models. Two dimensions of interpersonal and production are encompassed. The interpersonal dimension deals mainly with the social roles translators take and their relationship with clients, and it involves such elements as selfevaluation, planning, and management. It has the following sub-competences:

- Being aware of the social role of the translator

- Knowing how to follow market requirements and job profiles (knowing how to remain aware of developments in demand)

- Knowing how to organize approaches to clients/potential clients (marketing)

- Knowing how to negotiate with the client (to define deadlines, tariffs/invoicing, working conditions, access to information, contract, rights, responsibilities, translation specifications, tender specifications, etc.)

- Knowing how to clarify the requirements, objectives, and purposes of the client, recipients of the translation and other stakeholders

- Knowing how to plan and manage one's time, stress, work, budget, and ongoing training (upgrading various competences)

- Knowing how to specify and calculate the services offered and their added value

- Knowing how to comply with instructions, deadlines, commitments, interpersonal competences, team organization

- Knowing the standards applicable to the provision of a translation service 
- Knowing how to comply with professional ethics

- Knowing how to work under pressure and with other experts, with a project head (capabilities for making contacts, for cooperation and collaboration), including in a multilingual situation

- Knowing how to work on a team, including a virtual team

- Knowing how to self-evaluate lquestioning one's habits; being open to innovations; being concerned with quality; being ready to adapt to new situations/conditions) and take responsibility

Previous models have included these elements in the strategic competence category. Professional standards observation and teamwork were the other aspects. The production dimension deals with text translation in line with translation situation and the client's request. Finally, proper metalanguage is essential for the justification of decisions and discussion of issues with the clients. This dimension deals with the following sub-competences:

- Knowing how to create and offer a translation appropriate to the client's request, i.e., to the aim/skopos and to the translation situation

- Knowing how to define stages and strategies for the translation of a document

- Knowing how to define and evaluate translation problems and find appropriate solutions

- Knowing how to justify one's translation choices and decisions

- Mastering the appropriate metalanguage (to talk about one's work, strategies, and decisions)

- Knowing how to proofread and revise a translation (mastering techniques and strategies for proofreading and revision)

- Knowing how to establish and monitor quality standards

\section{Language competence}

This competence is defined as grammatical systems as well as repertoires, terminologies, syntactic, and morphological conventions; it is related to the language competence proposed by previous models (Neubert, 2000; PACTE, 2003). The following sub-competences are categorized under "language competence":

- Knowing how to understand grammatical, lexical and idiomatic structures and the graphic and typographic conventions of language $A$ and one's other working languages $(B, C)$

- Knowing how to use these same structures and conventions in $A$ and $B$

- Developing sensitivity to changes in language and developments in languages (useful for exercising creativityl

\section{Intercultural competence}

This competence encompasses a sociolinguistic dimension and a textual dimension. The former is what previous models called "intercultural competence." The textual dimension entailed several elements, including finding and comparing cultural features along with the ability to analyze the text's macrostructure and coherence to reproduce it according to particular genre conventions and rhetorical standards (PACTE, 2003). The sociolinguistic dimension encompasses the following sub-competences:

- Knowing how to recognize function and meaning in language variations (social, geographical, historical, stylisticl 
- Knowing how to identify the rules for interaction relating to a specific community, including nonverbal elements (useful knowledge for negotiation)

- Knowing how to produce a register appropriate to a given situation for a particular document (written) or speech (oral)

- The textual dimension's sub-competences include:

- Knowing how to understand and analyze the macrostructure of a document and its overall coherence (including where it consists of visual and sound elements)

- Knowing how to grasp the presuppositions, the implicit, allusions, stereotypes, and intertextual nature of a document

- Knowing how to describe and evaluate one's problems with comprehension and define strategies to resolve them

- Knowing how to extract and summarize the essential information in a document lability to summarizel

- Knowing how to recognize and identify elements, values, and references proper to the cultures represented

- Knowing how to bring together and compare cultural elements and methods of composition.

- Knowing how to compose a document in accordance with the conventions of the genre and rhetorical standards

- Knowing how to draft, rephrase, restructure, condense, and proofread rapidly and well lin languages $A$ and $B$ l

\section{Information mining competence}

This competence deals with the development of strategies to conduct documentary and terminological research. This is a fundamental requirement for working with experts and using technological tools effectively. The following sub-competences are included under "information mining competence":

- Knowing how to identify one's information and documentation requirements

- Developing strategies for documentary and terminological research lincluding approaching experts)

- Knowing how to extract and process relevant information for a given task (documentary, terminological, phraseological information)

- Developing criteria for evaluation vis-à-vis documents accessible on the Internet or any other medium, i.e., knowing how to evaluate the reliability of documentary sources (critical mind)

- Knowing how to use tools and search engines effectively (e.g., terminology software, electronic corpora, electronic dictionariesl

- Mastering the archiving of one's own documents

\section{Thematic competence}

Translators need to expand their knowledge of specialist fields, the related concepts and the associated terminologies, to comprehend different themes. This is how "thematic competence" is understood as an essential element of the framework. Its sub-competences include:

- Knowing how to search for appropriate information to gain a better grasp of the thematic 
aspects of a document (cf. Information mining competence)

- Learning to develop one's knowledge in specialist fields and applications (mastering systems of concepts, methods of reasoning, presentation, controlled language, terminology, and morel (learning to learn)

- Developing a spirit of curiosity, analysis, and summary

\section{Technological competence}

This competence deals with using documentary search or translation assistance software tools effectively. It encompasses the following sub-competences (EMT expert group, 2009):

- Knowing how to effectively and rapidly use and integrate a range of software to assist in correction, translation, terminology, layout, documentary research (for example text processing, spell and grammar check, the Internet, translation memory, terminology database, voice recognition softwarel

- Knowing how to create and manage a database and files

- Knowing how to adapt to and familiarize oneself with new tools, particularly for the translation of multimedia and audiovisual material

- Knowing how to prepare and produce a translation in different formats and for different technical media

- Knowing the possibilities and limits of MT

Although some of the components of the EMT model were presented in previous models, some components were not mentioned at all, such as the translation service provision competence that encompasses some subcomponents such as working under pressure, or the information mining competence, which includes critical evaluation of one's sources. EMT is somehow an expanded amalgamation of previous models underscoring more comprehensively, the technological aspects of competence. Its components take into consideration practical and market-oriented skills. Some abstract concepts of early models, such as transfer (PACTE, 2000) are excluded from the framework (Chodkiewicz, 2012). It is also revealed from the literature that there is a shift in the important role of the competences: from language competence (PACTE, 2003) to translation provision services competence (Neubert, 2000). Furthermore, the textual dimension for the intercultural competence, including such activities as rephrasing, proofreading and drafting, is improved in this framework (EMT expert group, 2009).

\section{Theoretical background}

The term "need" refers to the gap that exists between the current and desired results. The definition of this term will be important in the achievement of success, or on the other hand, failure. Moreover, the identification of needs will determine the functional ends to lead the planner to find and choose the best means for reaching those ends, rather than planning based on assumptions of the ends, which are unwarranted. Attending to needs is important because the term may be synonymous with such terms as gap, problem, issue, and discrepancy. The term "assessment" is used as a synonym for counting or estimating. It is a specialized evaluation type. Assessment in the business world 
is known as market analysis. Needs assessment is the tool to provide constructive and positive change. This change is functional, rational, and logical. Needs assessment is a fundamental step for any human resource development (HRD). The focus of needs assessment may be either on individuals per se or on individuals who form units or groups. Among the several situations where needs assessment is normally conducted, such as solving an existing problem, avoiding a previous problem, and taking advantage of a potential opportunity, it may be used to provide plans for learning, growth, and development. Thus needs assessment may be viewed as a diagnostic process that relies heavily on data collection to identify the learning or performance gaps to verify future actions (Gupta, 2011). Several benefits are attributed to needs assessment. They include framing problems and opportunities for people having a stake in the issue, providing the basis for planning and action to improve performance or training, aligning resources with strategies, building connections among stakeholders, clarifying opportunities and problems, specifying goals for prospective actions, and prioritizing actions (Gupta, 2011).

Kaufman, Herman, and Watters (2002) define needs assessment as a process that involves the determination of the existing gaps between the current and desired outcomes, the ordering of the gaps based on priority, and lastly selecting the most important resolution. These scholars provide the taxonomy of needs assessment modes, including Alpha, Beta, Gamma, Delta, Epsilon, and Zeta. The several needs assessment modes differ according to the availability of data as well as the restrictions imposed on needs assessment. In an Alpha mode there is high dependence on the people's contribution that will lead to policy formulation. The Beta type starts with the identification of perceived needs, analysis of the needs, assigning of the priorities, and finally designing a program to meet those needs. The Gamma mode deals with sorting the existing goals. Based on the resulted ranking, the school system will provide alternative programs or materials.

The fourth mode, Delta, deals with discrepancy-determination and involves the implementation of alternatives and managing of the outcomes. Epsilon, as the fifth mode, determines the extent to which the intended results are accomplished, and it deals with summative evaluation. The final mode, Zeta, is concerned with a constant and continual change of system or its renewal. However, taking into consideration the definitions provided by Kaufman et al. (2002), for the present study a Gamma needs assessment was taken into consideration as it sought to sort priorities and emphasize alternative materials or programs for schooling.

Yet, these modes can be separated into two types of views: external and internal. The internal view of education relates to the existing situation of the education. In this type, the changes exerted will be viewed by an organization; thus, the frame of reference for any decision making is the organizational context, its history, policies, and procedures. It is also assumed that the organization itself is the best starting point for planning, modification, and implementing decisions.

On the other hand, the external view relates to the way education should start. In fact, the accomplishments and actions of organizations that deal with education is the concern of the people outside of the organization. Accordingly, the external referent is the basic for planning, designing, evaluating, and implementing because the individuals must survive and contribute in the work world. 
Concerning the present study, the view taken is of an external type because the attempt is to focus on people in the work world and their contributions to societal relationships. Thus the accomplishments are important to people who are external to the organization, that is, to the translators who must contribute successfully to the translation business outside of the context of institutions where translation is studied.

\section{METHOD}

To research the compatibility of EMT framework with non-European professional translators' needs, a descriptive-survey approach was taken.

\section{Participants}

The participants of this study were selected according to stratified random selection technique from Proz.com, which is the largest community of translators worldwide. Overall, 300,000 translators and interpreters are registered with Proz.com from a combination of 190 countries and languages in the world. Pym, Orrego-Carmona and Torres-Simón (2016) maintains that although ProZ.com is the largest translators' community in the world, it has some shortcomings, such as the presence of nonprofessional translators, paying members ranked above nonpaying members regardless of their expertise, the correlation between the translator's status and his/her profile appearance in the directory, among others (see Pym et al., 2016, pp. 38-40 for a comprehensive overview). However, these shortcomings are not considered as limitations for the present study because first, only professional translators were selected for the purpose of this research (taking into account PACTE 2008 definition); and second, the translators' ranks were not used as the bases for inclusion or exclusion.

A total number of 250 (54.24\% female and $45.76 \%$ male) participants from 34 nationalities and 21 languages were selected for this study. Among the participants, 54.24\% were female and $45.76 \%$ male participants, aged from 18 to more than 45 years $(18-25$ years $=6.78 \%, 26-35$ years $=36.16 \%$, 3645 years $=27.68 \%$, and more than 45 years $=29.38 \%)$. The qualification degree of the participants was diverse, ranging from diploma or the equivalent to associate degree, from 116 fields of study.

The Tables 1, 2, and 3 displays comprehensive data in terms of the participants' number, language, nationality, qualification, and experience.

\section{Measures}

The instrument used for this study was a " 5 -point Likert-scale" translation competence questionnaire with items developed according to the EMT framework and Chodkiewicz's (2012) study. A panel of professionals including five professors and two experienced translators reviewed the items and suggested some modifications that resulted in developing a 40-item questionnaire (see Appendix A). 
Tabla 1

Survey participants' nationality frequencies

\begin{tabular}{|c|c|c|}
\hline $\mathrm{N}^{\circ}$ & Nationality & Frequency \\
\hline 1 & Brazilian & 24 \\
\hline 2 & Iranian & 15 \\
\hline 3 & Indian & 13 \\
\hline 4 & Egyptian & 12 \\
\hline 5 & Malaysian & 12 \\
\hline 6 & American & 10 \\
\hline 7 & Canadian & 10 \\
\hline 8 & Japanese & 9 \\
\hline 9 & Argentinian & 8 \\
\hline 10 & Chilean & 6 \\
\hline 11 & Chinese & 6 \\
\hline 12 & Thai & 6 \\
\hline 13 & Vietnamese & 6 \\
\hline 14 & Bengalis & 5 \\
\hline 15 & Korean & 5 \\
\hline 16 & Mexican & 4 \\
\hline 17 & Moroccan & 3 \\
\hline 18 & Cameroonian & 2 \\
\hline 19 & Colombian & 2 \\
\hline 20 & Lebanese & 2 \\
\hline 21 & Peruvian & 2 \\
\hline 22 & Syrian & 2 \\
\hline 23 & Uruguayan & 2 \\
\hline 24 & Australian & 1 \\
\hline 25 & Costa Rican & 1 \\
\hline 26 & Ecuadorian & 1 \\
\hline 27 & Guatemalan & 1 \\
\hline 28 & Hong Kong & 1 \\
\hline 29 & Iraqi & 1 \\
\hline 30 & Ivorian & 1 \\
\hline 31 & Jordanian & 1 \\
\hline 32 & Palestinian & 1 \\
\hline 33 & Venezuelan & 1 \\
\hline 34 & Yemenian & 1 \\
\hline
\end{tabular}

Tabla 2

Survey participants' qualification frequencies

\begin{tabular}{|l|c|c|c|}
\hline Qualification & Freq. & Percent & Cum. \\
\hline Associate degree & 1 & 0.56 & 0.56 \\
\hline Bachelor's degree & 85 & 48.02 & 48.59 \\
\hline Doctorate degree & 13 & 7.34 & 55.93 \\
\hline High school graduate & 2 & 1.13 & 57.06 \\
\hline Master's degree & 61 & 34.46 & 91.53 \\
\hline Some college credits & 7 & 3.95 & 95.48 \\
\hline Trade/technical/vocational & 1 & 0.56 & 96.05 \\
\hline training & & & \\
\hline Diploma or the equivalent & 7 & 3.95 & 100 \\
\hline Total & $\mathbf{1 7 7}$ & $\mathbf{1 0 0}$ & \\
\hline
\end{tabular}

Tabla 3

Survey participants' experience frequencies

\begin{tabular}{|c|c|c|c|}
\hline Experience & Frequency & Percent & Cumulative \\
\hline $1-5$ & 38 & 21.47 & 21.47 \\
\hline $6-10$ & 51 & 28.81 & 50.28 \\
\hline $11-15$ & 39 & 22.03 & 72.31 \\
\hline $16-20$ & 19 & 10.73 & 83.04 \\
\hline More than 21 & 30 & 16.95 & 100 \\
\hline Total & $\mathbf{4 5 6}$ & $\mathbf{1 0 0}$ & \\
\hline
\end{tabular}


The content validity of the questionnaire was checked out by asking a panel of experts to comment on the questionnaire. Also, a pilot study was run to calculate the reliability index of the developed questionnaire. A Cronbach alpha estimation resulted in an alpha level of 0.877 , which demonstrated an acceptable level of reliability. Moreover, a Confirmatory Factor Analysis (CFA) was conducted to evaluate the construct validity.

For this CFA model, the chi-square value was 1.83 and $p$-value equaled 0.07 . Moreover, GFI (Goodness-of-fit-Index) value (0.97) met the criteria (0.90 or larger) for an acceptable model fit. Similarly, RMSEA (Root Mean Square of Error Approximation) as a population-based index indicates the amount of unexplained variance or residual (Brown, 2014). RMSEA is an absolute measure for evaluating fitness of the model (Kenny, Kashy \& Cook, 2006). Little (2009) recommends the RMSEA to be smaller than 0.08 for the test to have an acceptable fit. Thus, the RMSEA was 0.07 , which is lower than the criterion value. It is concluded that the model was fit.

Results of the Confirmatory Factor Analysis (CMIN $=14.66, \mathrm{GFI}=0.97, \mathrm{RMSEA}=0.07[\mathrm{IC} 90 \%=$ $0.00,0.12]$ indicate that all fit model statistics are acceptable, which confirmed the factor structure. Moreover, path diagram shows the graphical representation of cause-and-effect relationships of the theory. The following abbreviations are used for the competences:

- TSPC: Translation Service Provision Competence

- LC: Language Competence

- ITC: Intercultural Competence

- IMC: Information Mining Competence

- THC: Thematic Competence

- TEC: Technological Competence

As shown in Fig. 2, the latent variable of "compatibility" was inferred and not directly observed from other observed components. The path diagram displays the standardized regression weights or factor loadings for the variable "compatibility" and each of its indicators. The following figure (Fig. 2) demonstrates the standardized estimates.

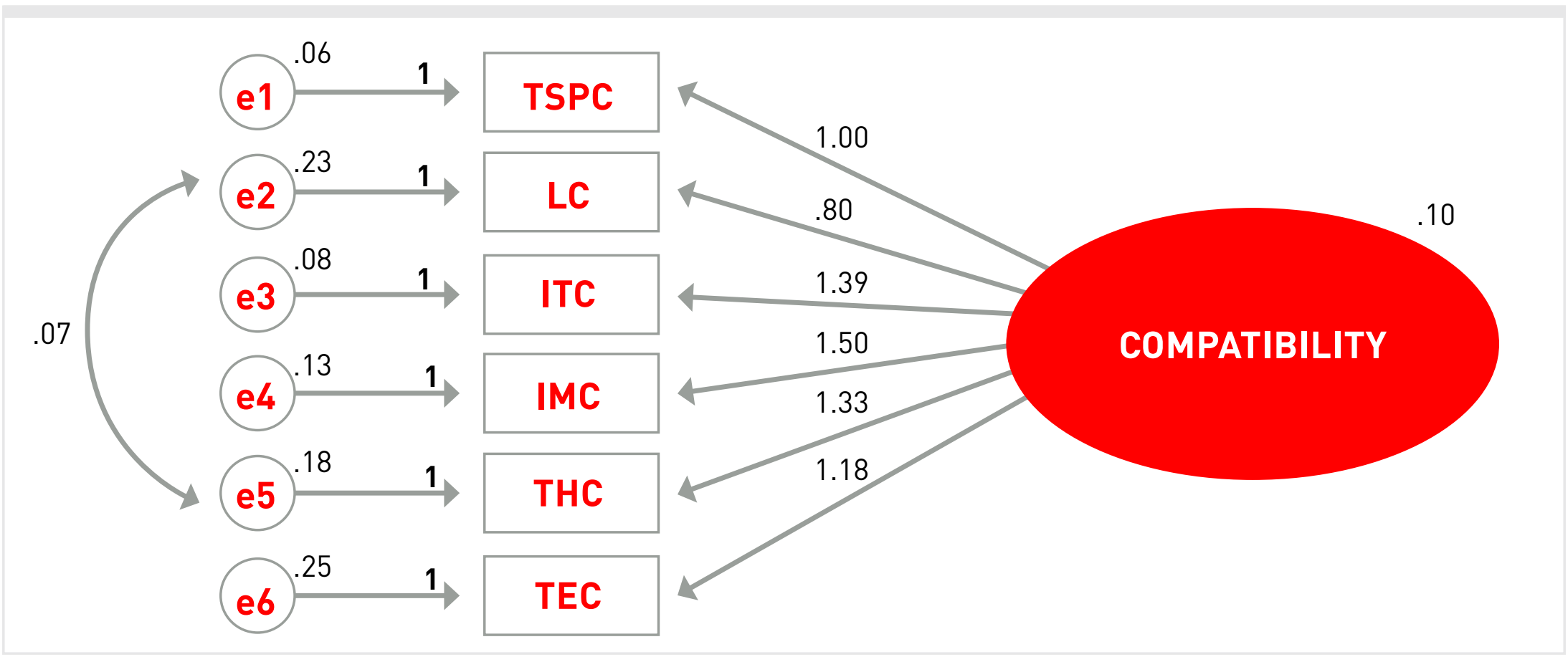

Figura 2. Standardized estimates for the variable compatibility 
As previously mentioned, the fitted values are all accepted (RMSEA $<0.07$ and GFI $>0.97$ ); thus, it is possible to measure the latent variable (importance) according to the observed variables (TSPC [1.00], LC [0.80], ITC [1.39], IMC [1.50), THC [1.33], and TEC [1.18]). Because CFA is conducted to evaluate construct validity, the analysis proved the construct validity of the questionnaire.

\section{Procedure}

To measure reliability of the questionnaire, a pilot study was conducted after the development of the questionnaire. The prepared questionnaire was sent to 250 professional translators selected from Proz.com based on the specified criteria of having five years of experience and working full-time lto be considered as a professional translator based on PACTE's 2003 definition). The strata were distinguished based on major and minor pairs in Proz.com. E-mails in which the researcher had mentioned the intentions of the study and had explained the research procedure were sent to the respondents' e-mail addresses provided in their profiles in the Proz.com Web site to obtain the participants' consent. A total number of 177 respondents replied through the LimeSurvey web site. LimeSurvey is well-known as a currently popular software used to conduct survey studies (Sappleton, 2013). The application was then installed on the domain, which was purchased by the researcher for the purpose of the study, and the survey was designed by the application of the downloaded LimeSurvey.

\section{Data analysis}

SPSS (Statistical Program for Social Sciences) version 21 was used for data analyses procedures which entailed the numerical ratings (from 1 to 5 ) based on the respondents' responses. Data analyses included descriptive statistics and the ratings' mean scores and standard deviations of every item. The next phase was identifying the most and the least compatible competences based on the professional translators' opinions, which was conducted by tabulating the data in SPSS.

\section{RESULTS}

\section{Descriptive Statistics}

Table 4 represents the ratings for all 40 items in the developed questionnaire, along with mean scores and standard errors and deviations. Furthermore, each question's ranking was specified and indicated in Table 5.

As illustrated in Table 4, the maximum mean of the questions belonged to question number 22 that is "Knowledge of the linguistic structures in the source and target languages." (4.67 \pm 0.03$)$; on the other hand, the minimum mean related to question 12 that is "Being able to work in a team" (3.57 \pm 0.04$)$.

Based on the means, the questions were accordingly ranked. Thus, question number 22 received the maximum mean and also the first rank. By means of ranking, the next highest ranks related to questions 22 and 9, and the ranking continued to questions 12 and 1 with the lowest ranks (Table 5). 
Tabla 4

Questionnaire's items rating with Mean and Standard Errors (SE) and Deviations (SD)

\begin{tabular}{|c|c|c|c|c|c|c|c|c|c|c|}
\hline Stats & $q 1$ & q2 & q3 & $q 4$ & $q 5$ & q6 & q7 & q8 & q9 & $q 10$ \\
\hline Mean & 3.63 & 4.29 & 4.32 & 4.33 & 4.58 & 4.34 & 4.13 & 4.06 & 4.64 & 4.49 \\
\hline SD & 0.88 & 0.78 & 0.81 & 0.78 & 0.65 & 0.80 & 0.76 & 0.81 & 0.61 & 0.67 \\
\hline SE(Mean) & 0.07 & 0.06 & 0.06 & 0.06 & 0.05 & 0.06 & 0.06 & 0.06 & 0.05 & 0.05 \\
\hline stats & $q 11$ & $q 12$ & $q 13$ & $q 14$ & $q 15$ & $q 16$ & $q 17$ & q18 & $q 19$ & $q 20$ \\
\hline Mean & 4.08 & 3.77 & 4.20 & 4.10 & 4.30 & 3.97 & 4.10 & 4.38 & 3.98 & 4.19 \\
\hline SD & 0.77 & 0.89 & 0.75 & 0.75 & 0.71 & 0.85 & 0.77 & 0.71 & 0.92 & 0.80 \\
\hline SE(Mean) & 0.06 & 0.07 & 0.06 & 0.06 & 0.05 & 0.06 & 0.06 & 0.05 & 0.07 & 0.06 \\
\hline stats & $q 21$ & $q 22$ & q23 & q24 & $q 25$ & $\mathrm{q} 26$ & $q 27$ & $q 28$ & q29 & $q 30$ \\
\hline Mean & 4.37 & 4.76 & 4.58 & 4.38 & 4.01 & 4.19 & 4.19 & 4.27 & 4.15 & 4.23 \\
\hline SD & 0.74 & 0.56 & 0.73 & 0.70 & 0.83 & 0.80 & 0.76 & 0.70 & 0.79 & 0.70 \\
\hline SE(Mean) & 0.06 & 0.04 & 0.05 & 0.05 & 0.06 & 0.06 & 0.06 & 0.05 & 0.06 & 0.05 \\
\hline stats & q31 & q32 & q33 & q34 & q35 & q36 & $q 37$ & $q 38$ & q39 & $q 40$ \\
\hline Mean & 4.03 & 4.19 & 4.11 & 3.95 & 4.24 & 4.46 & 3.98 & 3.97 & 3.52 & 4.22 \\
\hline SD & 0.82 & 0.77 & 0.78 & 0.86 & 0.70 & 0.72 & 0.99 & 0.89 & 1.06 & 0.80 \\
\hline SE(Mean) & 0.06 & 0.06 & 0.06 & 0.07 & 0.05 & 0.05 & 0.07 & 0.07 & 0.08 & 0.06 \\
\hline
\end{tabular}

Tabla 5

Questionnaire's items ranking

\begin{tabular}{|c|c|c|c|c|c|c|c|c|c|c|}
\hline Stats & $q 1$ & $q 2$ & q3 & $q 4$ & q5 & $q 6$ & $q 7$ & q8 & q9 & $q 10$ \\
\hline Rank & 39 & 414 & 12 & 11 & 3 & 10 & 25 & 30 & 2 & 5 \\
\hline stats & $q 11$ & $q 12$ & $q 13$ & q14 & $q 15$ & $q 16$ & $q 17$ & $q 18$ & $q 19$ & $q 20$ \\
\hline Rank & 29 & 38 & 19 & 27 & 13 & 36 & 28 & 7 & 34 & 22 \\
\hline stats & q21 & $q 22$ & $q 23$ & q24 & $q 25$ & $q 26$ & q27 & $q 28$ & q29 & q30 \\
\hline Rank & 9 & 1 & 4 & 8 & 32 & 20 & 23 & 15 & 24 & 17 \\
\hline stats & q31 & q32 & q33 & q34 & q35 & q36 & q37 & q38 & q39 & $q 40$ \\
\hline Rank & 31 & 21 & 26 & 37 & 16 & 6 & 33 & 35 & 40 & 18 \\
\hline
\end{tabular}

Furthermore, the total score of each component was calculated by their sub-competences. Thus "language competence" had the maximum score compared to other main competences with a standard error of $0.03(4.49 \pm 0.03)$. Also, the technological competence received the minimum score (3.92 \pm 0.03 ) compared to the other components (Table 6). 


\section{Tabla 6}

Mean and standard error, deviation, and rank of components of compatibility questionnaire

\begin{tabular}{|l|c|c|c|c|}
\hline Components & Rank & M & SD & SE (Mean) \\
\hline Translation Service Provision Competence & 4 & 4.21 & 0.41 & 0.03 \\
\hline Language Competence & 1 & 4.61 & 0.45 & 0.03 \\
\hline Intercultural Competence & 3 & 4.22 & 0.03 & 0.04 \\
\hline Information Mining Competence & 5 & 4.09 & 0.41 & 0.03 \\
\hline Thematic Competence & 2 & 4.37 & 0.57 & 0.04 \\
\hline Technological Competence & 6 & 3.97 & 0.63 & 0.05 \\
\hline
\end{tabular}

Accordingly, as demonstrated in Table 6, "language competence" received the first rank with the maximum mean. Technological competence had the last rank with the minimum mean.

The results of this study indicated that the "language competence" has the highest rank for the main competences. "Thematic competence" was the second rank in the EMT competences framework. "Intercultural competence" and "Translation service provision competence" occupied the third and fourth ranks, respectively. The fifth and sixth ranks were determined by "Information mining competence" and “Technological competence," respectively.

As illustrated above, "language competence," the "thematic competence," and "intercultural competence" were the three highest ranks in the category. This finding can provide more insight to the planners for translation training programs. The professional translators' opinions resulting from their actual experience in the real world may be beneficial in preparing the students for the market.

\section{DISCUSSION}

The findings of the present study provide the most compatible competences with non-European professional translators. As mentioned in the results section, "language competence" obtained the highest rank among other competences, which means that it should be underscored in translator training programs. Language competence has also been used for defining translation competence (Lesznyák, 2007). The obtained results verified the Chodkiewicz (2012) study results, which has also listed "language competence as the highest rank among all other competences." Furthermore, the data revealed the sub-competences of language competence, including "linguistic structures of the source and target languages, reproduction of grammatical and lexical structures in the target language, and being sensitive to language change and development" are of crucial importance.

The results listed "thematic competence" as the second-ranked item, which highlights the fact that translator training programs should make an attempt to develop the students' knowledge in 
specialized fields by teaching the related concepts or terminologies. Although "thematic competence" was ranked high in this study, it received a relatively low level of significance in the Chodkiewicz (2012) study, occupying the fifth rank in translators' ratings. The third item was "cultural competence," which emphasizes the important role of translating as an intercultural communication via teaching the appropriate registers or the elements suitable to the working language cultures. Chodkiewicz (2012) reported this competence as the second-ranked competence following "language competence."

The fourth rank was associated to "translation service provision competence," and its relevant sub-competences, such as "negotiating with clients for deadlines or fees" and "clarifying the requirements of the clients." It necessitates that translator training programs train prospective translators to manage time, stress, and budget; find strategies for solving problems; and conform to the standards, deadlines, instructions, and professional ethics. Although this competence was not among the highest-ranked ones in the Chodkiewicz (2012) study, the participants' considered it as being highly important. The results of the present study overlap with the Chodkiewicz (2012) study for "translation service provision competence." This was quite unpredictable because this competence is the most practical one in the EMT framework.

The last two items in the list were "information mining competence" and "technological competence," which gained no significant attention by the expert translators. However, the subcompetence of "the effective use of computer tools" received a high rank. Based on this finding, including them in translator training courses is recommended. It is worth mentioning here that although "technological competence" gained the last rank of compatibility, its sub-competence of "the effective use of computer tools" was considered significant by professional translators. This finding converges with the findings of European Language Industry Survey (2016), which concluded that the language industry and technology are highly intertwined. The results of this survey illustrate that only $7 \%$ of translation companies are not using computer-aided or machine translation, while $40 \%$ are doing so. Overall, $84 \%$ of companies are using technology in their profession in some way. This has become an important criterion for the translation industry and recruitment, and as such, should be taken into serious consideration.

Chodkiewicz (2012), who investigated professional and translation students' views regarding the EMT competences, reported that translation students place more significance than professional translators on all competences apart from the technological competence. Although the average ratings were fairly similar for both groups, it was revealed that "intercultural competence," "language competence," and "information mining competence" ranked highest among all competences. Furthermore, "technological competence" received the lowest rank in these ratings. These findings are almost in line with the findings of the present study.

The findings of this study can provide a better insight for material developers and planners of translator training programs to build emphasis on the most important competences. The results can also enhance the prospective translators' knowledge and skills to influence them to act more professionally in the translation market. 


\section{REFERENCIAS}

2016 European language industry survey: Expectations and concerns of the European language industry. (2016). Retrieved from https://www. gala-global.org/ondemand/2016-european-language-industry-survey-expectations-and-concerns-european-language-industry [sólo accesible para miembros de GALA]

Brown, T. (2014). Confirmatory factor analysis for applied research. New York: Guilford Publications.

Chodkiewicz, M. (2012). The EMT framework of reference for competences applied to translation: Perceptions by professional and student translators. Jostrans-The Journal of Specialised Translation, 17, 37-54.

EMT Expert Group. (2009). Competences for professional translators, experts in multilingual and multimedia communication. Retrieved from http://ec.europa.eu/dgs/translation/programmes/emt/key_documents/emt_competences_translators_en.pdf

Gupta, K. (2011). A practical guide to needs assessment. New York: John Wiley \& Sons.

Kaufman, R., Herman, J., \& Watters, K. (2002). Educational planning: Strategic, tactical, operational. New Jersey: Scarecrow Press.

Kelly, D. (2005). A handbook for translator trainers. Manchester: St. Jerome.

Kenny, D. A., Kashy, D. A., \& Cook, W. L. (2006). Dyadic data analysis. New York: Guilford Press.

Kiraly, D. (2003). From instruction to collaborative construction: A passing fad or the promise of a paradigm shift in translator education. In B. Brian \& K. Geoffrey (Eds.), Beyond the ivory tower: Rethinking translation pedagogy (pp. 3-27). Amsterdam, Filadelfia: John Benjamins Publishing Company.

Kiraly, D. (2004). Preparing students today to meet market demands tomorrow. In M. Forstner \& H. Lee-Jahnke (Eds.), Internationales CIUTIForum: Marktorientierte Translationsausbildung (pp. 101-118). Bern: Peter Lang

Lesznyák, M. (2007). Conceptualizing translation competence. Across Languages and Cultures, 8(2), 167-194. doi:http://dx.doi.org/10.1556/ Acr.8.2007.2.2

Little, T. D. (2009). Longitudinal structural equation modeling. New York: Guilford Press.

Mayoral, R. (2003). Notes on translator training. In A. Pym, C. Fallada, J. R. Biau, \& J. Orenstein (Eds.), Innovation and E-learning in translator education (pp. 1-6). Tarragona: Intercultural Studies Group of Universitat Rovira i Virgili.

Neubert, A. (2000). Competence in language, in languages, and in translation. In C. Schäffner \& B. Adab (Eds.), Developing Translation Competence (pp. 3-18). Amsterdam/ Philadelphia: John Benjamins.

Olvera-Lobo, M.-D., Castro-Prieto, M.-R., Quero-Gervilla, E., Muñoz-Martín, R., Muñoz-Raya, E., Murillo-Melero, M., . . . Domínguez-López, C. (2005). Translator training and modern market demands. Perspectives: Studies in translatology, 13(2), 132-142. doi:http://dx.doi. org/10.1080/09076760508668982

PACTE (2000). Acquiring Translation Competence: Hypotheses and Methodological Problems in a Research Project. In A. Beeby, D. Ensinger \& M. Presas (Eds.), Investigating Translation (pp. 99-106). Amsterdam: John Benjamins.

PACTE. (2003). Building a translation competence model. In F. Alves (Ed.), Triangulating translation: Perspectives in process oriented research (pp. 43-68). Amsterdam: John Benjamins.

PACTE (2008). First results of a Translation Competence Experiment: 'Knowledge of Translation' and 'Efficacy of the Translation Process'. In J. Kearns (Ed.), Translator and Interpreter Training. Issues, Methods and Debates (pp. 104-126) Londres: Continuum.

Pym, A. (2008). On a proposed European Masters in Translation. Retrieved from http://www.tinet.cat/ apym/on-line/training/2008_eu_masters.pdf

Pym, A., Orrego-Carmona, D., \& Torres-Simón, E. (2016). Status and technology in the professionalization of translators. Market disorder and the return of hierarchy. The Journal of Specialised Translation, 25(1), 33-53.

Sappleton, N. (2013). Advancing research methods with new technologies. Hershey \& London: Idea Group Reference.

Schmitt, P. A. (2012). Bologna, EMT and CIUTI-Approaches to high quality in translation and interpretation training. Meta: Journal des traducteursMeta:/Translators' Journal, 57(1), 23-34. doi:http://dx.doi.org/10.7202/1012738ar

(c) Los autores. Este artículo es publicado por la Revista Digital de Investigación en Docencia Universitaria del Área de Institutional Research and Effectiveness de la Dirección de Aseguramiento de la Calidad, Universidad Peruana de Ciencias Aplicadas. Este es un artículo de acceso abierto, distribuido bajo los términos de la LicenciaCreativeCommons Atribución-Compartirlgual 4.0 Internacional.I http://creativecommons.org/licenses/bysa/4.0/l, que permite el uso no comercial, distribución y reproducción en cualquier medio, siempre que la obra original sea debidamente citada. 
No TYPES OF COMPETENCE

1

2

Awareness of the translator's social role.

Awareness of market demands.

Being able to negotiate with potential clients.

Negotiation with clients regarding deadlines and fees

Clarifying client's requirements.

Management of time, stress, and budget.

Planning to upgrade competences by constant training

Specification and calculation of the services offered.

Compliance with instructions, deadlines, and standards.

Compliance with professional ethics.

Compliance with interpersonal competences.

Being able to work in a team.

Doing self-evaluation and taking responsibility.

Awareness of the constraints of the translation context.

Awareness of the suitability of the translation to be provided.

Defining strategies for the translation of a document.

Defining translation problems appropriately.

Finding ways to solve translation problems appropriately.

Justification of translation choices and decisions.

Being able to establish quality standards.

Sensitivity to language changes and developments.

Knowledge of the linguistic structures in the source and

target languages.

Being able to reproduce the grammatical and lexical

structures in another language.

Recognize function and meaning in language variations

(social and geographical).

Identification of interactional rules in a specific community

including non-verbal elements.

Using appropriate register for a given document

Understanding of the macrostructure and overall coherence of documents.

Recognize elements proper to the cultures of your working

languages.

Extraction of the essential information in a document

Compose a document in accordance with the conventions of

the genre and rhetorical standards of the source and target

languages.

Identification of documentation requirements.

Development of strategies for research into subject-matter

and terminology (including expert consultation).

Extraction of relevant information for given tasks

(documentary, terminological, phraseological information).

Development of criteria for the evaluation of documents

accessible on Internet or other media.

Searching for appropriate information for the thematic aspects of a document.

Development of knowledge in specialized fields /concepts and terminologyl.

Awareness of the possibilities and limitations of machine translation.

Familiarization with new translation-related tools, especially for the translation of multimedia materials.

Producing translations in different formats for

different media.

Effective use of a range of computer tools in translation,

terminology, and research.

SECTION III:

If you are interested in knowing the results of the present study, please provide your email address. You will be informed of the results when all of the data are processed and analyzed. 